11. Demianenko, M. Ya. Finansovyi slovnyk-dovidnyk [Text] M. Ya. Demianenko, Yu. Ya. Luzan, P. T. Sabluk, V. M. Skupyi et al.; ed. by M. Ya. Demianenka. - Kyiv: IAE UAAN, 2003. $555 \mathrm{p}$.

12. Donets, L. I. Ekonomichni ryzyky ta metody yikh vymiriuvannia [Text]: Handbook / L. I. Donets. - Kyiv: TsUL, 2006. - 312 p.

13. Morgan, J. P. Risk Metrics-Technical Document [Electronic resource] / J. P. Morgan. - New York, 1996. - Available at: \www/ URL: https://www.msci.com/documents/10199/5915b101-42064ba0-aee2-3449d5c7e95a

14. Smeliantsev, A. P. Problema zahroz interesam bezpeky Ukrainy (sotsialno-filosofskyi analiz) [Text]: Abstract's PhD thesis / A. P. Smeliantsev. - Kharkiv, 2001. - 18 p.

15. Liashenko, O. M. Kontseptualizatsiia upravlinnia ekonomichnoiu bezpekoiu pidpryiemstva [Text]: Monograph / O. M. Liashenko. Luhansk: SNU im. V. Dalia, 2011. - 400 p.

16. Kozhenevski, L. Sekyuritologiya - nauka o bezopasnosti w zjednoczonej europie [Electronic resource] / L. Kozhenevski. - Available at: \www/URL: http://ua-ed.narod.ru/Kozhenyovski_L_Ednist bezpeky v Evrosoyuzi.htm/

17. Mochernoho, S. V. Ekonomichnyi slovnyk-dovidnyk [Text] / ed. by S. V. Mochernoho. - Kyiv: Femina, 1995. - 368 p.

18. Rudnichenko, Ye. M. Zahroza, ryzyk, nebezpeka: sutnist ta vzaiemozviazok iz systemoiu ekonomichnoi bezpeky pidpryiemstva [Text] / Ye. M. Rudnichenko // Ekonomika Menedzhment Pidpryiemnytstvo. - 2013. - No. 25 (1). - P. 188-195

19. «Top 200 Ukraina» 2017: Innovatsiinist i suspilna zatrebuvanist - holovni kryterii diialnosti [Electronic resource] // Anews. - Available at: \www/URL: http://www.anews.com/ ua/p/74631312-top-200-ukrayina-2017-innovacijnist-i-suspilna-zatrebuvanist-holovni-kryteriyi-diyalnosti/

20. Intehralnyi pokaznyk diialnosti VNZ Ukrainy za rezultatamy vyznachennia reitynhiv universytetiv Ukrainy III, IV rivniv akredytatsii «Top-200 Ukraina» u 2014 rotsi [Electronic resource] // HO Tsentr mizhnarodnykh proektiv «Yevroosvita». May 30, 2014. - Available at: \www/URL: http://www.euroosvita.net $/$ index.php/?category $=1 \&$ id $=3281$

21. Intehralnyi pokaznyk diialnosti VNZ Ukrainy za rezultatamy vyznachennia reitynhiv universytetiv Ukrainy III, IV rivniv akredytatsii «Top-200 Ukraina» u 2015 rotsi [Electronic resource] // HO Tsentr mizhnarodnykh proektiv «Yevroosvita». Available at: \www/URL: http://www.euroosvita.net/index. $\mathrm{php} /$ ? category $=42 \&$ id $=4068$
22. Lynovytska, O. Universytetski reitynhy, yak nevidiemna skladova intehratsiinykh protsesiv $\mathrm{v}$ ekonomitsi i suspilstvi rotsi [Electronic resource] / O. Lynovytska // HO Tsentr mizhnarodnykh proektiv «Yevroosvita». - May 27, 2016. - Available at: \www/URL: http://www.euroosvita.net/index.php/ ?category $=1 \&$ id $=4757$

23. Peremishcheni VNZ: try roky na novomu mistsi [Electronic resource] / Vyshcha osvita. - December 19, 2016. - Available at: \www/URL: http://vnz.org.ua/statti/9793-peremischennivnz-try-roky-na-novomu-mistsi

24. Breus, S. V. Vykorystannia zbalansovanoi systemy pokaznykiv u diialnosti vyshchykh navchalnykh zakladiv [Text] / S. V. Breus, Ye. B. Khaustova // Aktualni problemy ekonomiky. - 2016. No. 9 (183). - P. 109-116.

\section{ИССЛЕДОВАНИЕ РИСКА В ДЕЯТЕЛЬНОСТИ ВЫСШИХ УЧЕБНЫХ ЗАВЕДЕНИЙ В КОНТЕКСТЕ ОБЕСПЕЧЕНИЯ ИХ ЭКОНОМИЧЕСКОЙ БЕЗОПАСНОСТИ}

Проведен анализ понятия «риск», при этом учтено его значение в контексте обеспечения экономической безопасности и надежности защиты интеллектуального капитала высших учебных заведений, перемещенных с временно оккупированных территорий. Рассмотрены экономические последствия от их перемешения путем анализа изменения рейтинговых позищий этих ВУЗов за 2013-2017 годы со сравнением надежности защиты инновационного и человеческого капитала.

ключевые слова: высшие учебные заведения (ВУЗы), экономическая безопасность ВУЗов, защита инновационного и человеческого капитала.

Kasych Alla, Doctor of Economic Sciences, Professor, Head of the Department of Management, Kyiv National University of Technologies and Design, Ukraine, e-mail: Kasich.alla@gmail.com, ORCID: https://orcid.org/0000-0001-7019-1541

Breus Svitlana, PhD, Associate Professor, Department of Business Economics, Kyiv National University of Technologies and Design, Ukraine, e-mail: breus_sv@ukr.net, ORCID: http://orcid.org/00000003-0624-0219

Khaustova Yevheniia, PhD, Associate Professor, Department of Accounting and Audit, Kyiv National University of Technologies and Design, Ukraine, e-mail: g.haystova@gmail.com, ORCID: http:// orcid.org/0000-0003-1436-6137

\section{Solodova 0. Golubyonkova $\mathbf{0}$.}

\title{
RESEARCH OF FACTORS THAT INFLUENCE THE TRADEMARK POLICY OF AN ENTERPRISE
}

Проведено дослідження класифікащї торгових марок, уточнено поняття бренду та торгової марки. Розглянуто процес формування портфелю торгових марок на прикладі одного з провідних виробників алкогольної продукції - ТОВ «ПТК «Шабо» (с. Шабо, Одеська обл., Україна). Запропоновано перелік чинників, які необхідно враховувати при прийнятті рішення щодо формування портфелю торгових марок.

Ключові слова: торгова марка, марочна політика, портфель торгових марок, виробники алкогольної продукції.

\section{Introduction}

In the current economic conditions, many international and local companies are faced with the issue of managing a large trademark portfolio. This issue is relevant due to the fact that during the period of active growth and development of companies, many new trademarks were created. At the same time, to increase the competitiveness 
of companies, it is not enough to develop trademarks, it is necessary to learn how to form and effectively manage a trademark portfolio. It should be noted that the analysis of the portfolio of trademarks is much more complicated than the traditional analysis of the business portfolio. This is due to the fact that management of the trademark is much broader and multi-faceted simple management of the product category.

In the face of tough competition, producers of alcoholic beverages should pay great attention to the formation of a portfolio of trademarksof their products. The globalization of this market leads to the fact that the consumer must make a choice among a large number of trademarks. On the other hand, wine is a specific commodity, not every consumer knows how to determine the level of quality, relying on their taste buds, recommendations of friends or consultants.

Today, every manufacturer solves the problem of optimizing expenses on a daily basis, including expenses for marketing activities. One of the most effective methods in this case is the formation of an optimal trademark portfolio.

\section{The object of research and its technological audit}

The object of research is the marketing activities of alcohol producers in the field of trademark policy.

Trademark policy today is one of the key marketing issues. There are manufacturers who have only one or two brands in their portfolio. For example, on family winemaking (Australia) Casella's family produces wine of one brand: Yellow Tail - Yellow tail and has sparkling red, white wine and sangria in its portfolio, the entire assortment consists of 23 items [1,2]. This approach primarily reduces the problem of choice for the consumer.

While Ukrainian producers sometimes have more than ten brands in their portfolio. For example, the alcohol holding Global Spirits (Ukraine) produces seven product categories (vodka, tincture, quiet wine, sparkling wine, cognac, brandy, vermouth) under 11 trademarks [3]. In this case, not identifying the manufacturer with trademarks.

The level of success of these manufacturers and the popularity of their brands is high. This gives grounds for searching for factors, it affects the trademark policy of alcohol producers.

\section{The aim and objectives of research}

The aim of research is formation of methodological approaches to the trademark policy of alcohol producers, will ensure a sufficient level of performance.

The following tasks are defined:

1. To clarify the concept of categories «trademark» and «brand».

2. To carry out a classification of types of trademarks.

3. To investigate the vintage policy of Ukrainian producers of alcoholic beverages.

4. To identify the main factors that influence the formation of the trademark portfolio.

\section{Research of existing solutions of the problem}

Many studies have been devoted to development and classification of trademarks and brands. Methods for the distribution of costs, monitoring of the company's portfolio of brands are reviewed in [4]. Work [5] is devoted to classification of promising and effective means of marketing and branding (including visual, auditory, olfactory and tactile). In work [6] practical recommendations on maximization of profitableness of trademarks by giving to them signs of a premium brand are given. As successful trademarks have become major brands, where consumers' feelings are built on the success of the brand, which leads to a significant growth of the company considered in [7-10]. The importance of classification and proper positioning of trademarks is discussed in [11, 12]. The influence of branding and its emotional component on consumer loyalty is investigated in five countries: Australia, Chile, Mexico, France and Portugal [13]. Based on a study of 20 Australian wine producers, the paper [14] identifies the main attributes that must be inherent in an authentic brand. At the same time, it is stressed that commercial profit is not the main factor. [15] shows the results of a consumer survey (California, USA) from 2008 to 2016, the relevance of the brand is the main factor in choosing a wine.

However, which factors affect the trademark policy should still be investigated. Let's note that the list of these factors depends on the product and in this study, attention is paid to alcoholic beverages.

\section{Methods of research}

To solve the tasks, the following methods are used: analysis and synthesis, logical generalization, analogies, comparative comparison.

\section{Research results}

One of the elements of the marketing complex is a trademark and a brand. However, there is some confusion about their definition. In work [11] a trademark is defined as «name, term, sign, design, emblem or combination of the above, intended for identification of goods or services of one or a group of sellers, as well as for differentiation from competitors». At the same time, it is emphasized that the brand is «a figurative combination of the product or service itself with a set of inherent characteristics, expectations and associations that arise in the consumer goods». Let's consider it expedient to define such trademark as «a sign of the origin of the product, identify it with a certain source registered in accordance with the law. Trademarks do not travel between countries without registration» [6].

That is, the concept of the brand is much broader than the trademark. A brand can be a name, a city name, a company name, a trademark, have a certain meaning and association and is recognized by consumers.

The key decision in marketing activity is the choice of strategy and the definition of the type of trademark policy.

The first solution is determination of the type of name: the only name for all products (brand of the manufacturer) or an individual name for each product category (standalone trademarks).

In [16], it is proposed to classify brands according to the following characteristics: the brand owner, the distribution region, the way of using the brand name, the competitive position. 
For classification of brands, the following classification criteria are proposed: brand scale, brand market segment, brand style, brand envelope, brand trademark bearer, brand association, consumer capture method, brand expansion strategy and user addition policy [17].

Let's consider it expedient to analyze the interrelations between brands using the following initial data:

- trademark architecture;

- the image of each brand;

- mission of the company, its strategic goals, as well as the mission and strategic objectives of each brand;

- profiles of consumers of each trademark;

- other indicators of trademark success (market share, degree of customer loyalty, recognition, performance of a brand contract, etc.).

Based on the classification [12] in the context of «commodity-market», let's consider it expedient to analyze the trademark portfolio as follows (Fig. 1).

\begin{tabular}{|c|c|c|c|}
\cline { 3 - 4 } \multicolumn{2}{c|}{} & \multicolumn{2}{c|}{ Trademark level } \\
\cline { 3 - 4 } \multicolumn{1}{c|}{} & $\begin{array}{c}\text { Corporate } \\
\text { trademark }\end{array}$ & $\begin{array}{c}\text { Merchandise } \\
\text { trademark }\end{array}$ \\
\hline $\begin{array}{c}\text { Trademark } \\
\text { role }\end{array}$ & Independent & $\begin{array}{c}\text { Classical corporate } \\
\text { trademark }\end{array}$ & $\begin{array}{c}\text { Leading } \\
\text { trademark }\end{array}$ \\
\cline { 2 - 4 } & Auxiliary & Supporting trademark & $\begin{array}{c}\text { Auxiliary } \\
\text { trademark }\end{array}$ \\
\hline
\end{tabular}

Fig. 1. The matrix of the trademarks analysis of the company [12]

The result of this analysis will be a set of strategic marketing solutions to manage the development of each trademarks of the company's portfolio.

Ukraine has a long tradition of winemaking and at the same time more than 400 modern wine producers that provide new technologies, new solutions for processing grapes and wine production, develop autochthon grape varieties, and offer new wines to the world. Geographically and historically, Ukraine belongs to the Old World. Mentally and technologically - in the New World. The study allows to assert that there is such trend: the New World, breaking traditions of the Old World, dictates fashion for organoleptic, external design and marketing of wines.

During the last 10-15 years, the popularity of wine in Ukraine has gradually increased. And yet experts of the relevant international market evaluate Ukraine as a country with a low culture of consumption of this product. So, the Ukrainian drank on average only 3.9 liters of wine for 2016. For comparison: the average European 20 liters, and for Europe this is not the maximum, and the average rate [18]

It is the «backlog» of vodka and beer in popularity that largely hinders the development of the wine segment, which capacity growth is annually until 2010. It amounted to about 5-6\%. It is possible to say that the wine market is developing not so much quantitatively as it is qualitatively, which is especially noticeable in the segment of quiet wines.

According to experts, Ukrainian passion for the style of the drink largely depends on the place of residence. The larger the city, the more popular it table wines. Perhaps, the fact that in the mega-cities the trends of the world fashion are getting more rapid. In small cities, the ratio of table and semisweet, sweet almost reached 50 to 50, although the latter are slightly larger [19].

Speaking about the color of wine, red still occupies a dominant position in the color structure of small cities. And among consumers with a population of 50 thousand + there is a tendency to increase consumption of white wines. And although the popularity of white wine is growing at a significant pace, the red one will not yield to the primacy for a long time due to the formed image of the most useful for health. However, here again the seasonality affects season's palette: the demand for light white wines rises in summer, and with the onset of coolness, sales of reds increase.

As for the price ranges, the most popular segment remains the lower one, it accounts for more than $60 \%$ of the realization of the drink. And yet, given the significant increase in sales in value terms, it is possible to note a trend towards an increase in the share of the upper segment. More and more Ukrainian prefer to buy wines of medium and higher average price groups, hoping that in this way they receive a quality guarantee. It can also be assumed that shifting the emphasis to more expensive wines is also associated with the development of a wine consumption culture in the country

In the Ukrainian wine market, the situation is further complicated by several factors:

- the presence of a large number of alcohol producers in the lower price segments, which increases competition within the market;

- the presence of a large number of different trademarks belonging to the same producers, disorient the consumer; - distrust of Ukrainian wine producers from the domestic consumer, which is exacerbated by the presence of a large number of low-quality products;

- the lack of a culture of consumption and an understanding of the quality of the guilty products of consumers;

- the growth of foreign competitors - manufacturers of wines of the New World, Chile, Australia (recently the influence of imported wines has been significantly reduced due to the increase in prices due to changes in the exchange rate).

Therefore, Ukrainian producers of wine products for effective management of the portfolio of trademarks should also distribute the brands on the price line and monitor the coverage of the target market. Investigating the coverage of the target market is important to avoid cannibalism and to ensure the satisfaction of variation in market demand.

The wine of Ukraine has the status of Wine with appellation of controlled origin (AOC). The first and only company that has this AOC mark is SHABO LLC, based in the village of Shabo, Odessa region (Ukraine). Several brands of wine from Ukraine are exported to the border countries, the European Union and North America.

Based on centuries-old traditions of Shabo winemaking in 2003, «Shabo» company was created - the Ukrainian winery complex with a full production cycle. The company's activities are directed to the cultivation and processing of grapes, the production and sale of alcohol products Shabo, created exclusively from selected grapes.

In a short time the enterprise became the leader of the industry. Today, a wide range of Shabo products are represented in all regions of Ukraine, as well as in Georgia, Israel, China, the Baltic countries, Russia, Slovakia, Finland and Japan [20]. 
So, for example, in the portfolio of the company LLC «Industrial and Trade Company «Shabo» (LLC «ITC «Shabo»), as of July 2015, there were sixteen trademarks. Given the high level of competition and certain state regulation of pricing policy, this year the composition of the company's trademarks has changed many times - certain trademarks and product categories were introduced to the market, while some had to be disposed of (Table 1).

«Shabo» in 2016 refuses to produce cheap brands «Royal Stories» and «Shabo Wines», which do not correspond to the positioning of the company as a producer of high-quality wines of «high scales». Due to the transition to a higher price segment, the product portfolio does not require these trademarks. The key brand in the company's product portfolio in 2016 is the «Shabo Classic» brand. The assortment of the line has been changed in order to preserve the key successful positions of the rulers «Royal Stories» and «Shabo Wines» (namely, such products as «Royal», «Shabo Cellar»,
«Cahors») were transferred to the line «Shabo Classic». This step allows to keep the current sales volume to the maximum, provided that the production volume is reduced. Thus, the brand «Shabo» leaves the «lower» price segment, moving into the «middle» and «premium» segments. The product line «Shabo Reserve» was expanded in 2016 to meet the growing demand for high-quality wines.

In order to develop the «Shabo» brand as a strong producer of European-quality wines in 2016, an additional brand is launched in the price segment «premium»«Grande Reserve».

Studies of taste trends among consumers of sparkling wine showed a high level of popularity of flavored wines in 2017. However, marketers and the management of «Shabo» decided not to introduce a new product - flavored sparkling wine due to the discrepancy between the positioning of the Shabo brand as a producer of high-quality products exclusively from quality raw materials.

Table 1

Trademarks optimization process LLC «ITC «Shaba» (5habo village, Odessa region, Ukraine)

\begin{tabular}{|c|c|c|c|c|c|}
\hline \multicolumn{3}{|c|}{2015} & \multicolumn{3}{|c|}{2016} \\
\hline Trademark (line) & Assortment & Distribution channels & Trademark (line) & Assortment & Distribution channels \\
\hline $\begin{array}{l}\text { Royal stories: } \\
\text { semisweet and dessert } \\
\text { wines. } \\
\text { Price for } 1 \text { bottle. } \\
35.00-38.00 \text { UAH } \\
\text { in retail }\end{array}$ & $\begin{array}{l}\text { White } \\
\text { Royal red } \\
\text { Royal cellar white } \\
\text { Royal cellar red } \\
\text { Muscat white } \\
\text { Bastardo dessert red } \\
\text { Cahors }\end{array}$ & $\begin{array}{l}\text { National and regional } \\
\text { network retail, line retail: } \\
\text { small shops near the } \\
\text { house, self-service shops. } \\
\text { Export markets of Asia }\end{array}$ & \multicolumn{3}{|c|}{ Production line is canceled due to position change } \\
\hline $\begin{array}{l}\text { Shabo wine: } \\
\text { varietal and semisweet } \\
\text { wines. } \\
\text { Price for } 1 \text { bottle. } \\
33.00-35.00 \mathrm{UAH} \\
\text { in retail }\end{array}$ & $\begin{array}{l}\text { Cabernet Chardonnay } \\
\text { Saperavi } \\
\text { Shabo Blanc } \\
\text { Shabo Bordeaux } \\
\text { Shabo Vine } \\
\text { Shabo cellar }\end{array}$ & $\begin{array}{l}\text { National and regional } \\
\text { network retail, line retail: } \\
\text { small shops near the } \\
\text { house, self-service stores }\end{array}$ & \multicolumn{3}{|c|}{ Production line is canceled due to position change } \\
\hline $\begin{array}{l}\text { Shaho classic: } \\
\text { high-quality varietal, } \\
\text { semisweet and dessert } \\
\text { wines. } \\
\text { Price for } 1 \text { bottle. } \\
40.00-58.00 \text { UAH } \\
\text { in retail }\end{array}$ & $\begin{array}{l}\text { Cabernet Chardonnay } \\
\text { Saperavi } \\
\text { Merlot } \\
\text { Pink dry } \\
\text { Sauvignon Blanc } \\
\text { White semi-dry } \\
\text { Red semi-dry } \\
\text { White semisweet } \\
\text { Red semisweet } \\
\text { Royal white } \\
\text { Royal red } \\
\text { Shabsa cellar white } \\
\text { Shabocellar red } \\
\text { Cahors }\end{array}$ & $\begin{array}{l}\text { National and regional } \\
\text { network retail, line retail: } \\
\text { small shops near the } \\
\text { house, self-service stores }\end{array}$ & $\begin{array}{l}\text { Shaho classic: } \\
\text { high-quality varietal, } \\
\text { semisweet and dessert } \\
\text { wines. } \\
\text { Price for } 1 \text { bottle. } \\
60.00-87.00 \text { UAH } \\
\text { in retail }\end{array}$ & $\begin{array}{l}\text { Cabernet Chardonnay } \\
\text { Saperavi } \\
\text { Merlot } \\
\text { Pink dry } \\
\text { Sauvignon Blanc } \\
\text { White semi-dry } \\
\text { Red semi-dry } \\
\text { White semisweet } \\
\text { Red semisweet } \\
\text { Shabo white semisweet } \\
\text { Shabo red semisweet } \\
\text { Sherry dry } \\
\text { Sherry dessert } \\
\text { Muscat dessert }\end{array}$ & $\begin{array}{l}\text { National and } \\
\text { regional network } \\
\text { retail, line retail: } \\
\text { small shops near } \\
\text { the house, self- } \\
\text { service stores }\end{array}$ \\
\hline $\begin{array}{l}\text { Shabo Reserve: } \\
\text { high-quality high-quality } \\
\text { varietal wines, aging in } \\
\text { a barrel from } 9 \text { months. } \\
\text { Price for } 1 \text { bottle. } \\
190.00-200.00 \text { UAH } \\
\text { in retail }\end{array}$ & $\begin{array}{l}\text { Cabernet Chardonnay } \\
\text { Saperavi } \\
\text { Merlat }\end{array}$ & $\begin{array}{l}\text { National and regional net- } \\
\text { work retail. Export markets } \\
\text { of Europe, Japan }\end{array}$ & $\begin{array}{l}\text { Shaho Reserve: high- } \\
\text { quality varietal wines, } \\
\text { aging in a barrel from } \\
9 \text { months. } \\
\text { Price for } 1 \text { bottle. } \\
\text { 200.00 UAH in retail } \\
\text { Shabo Reserve: high- } \\
\text { quality varietal wines, } \\
\text { aging in a barrel from } \\
9 \text { months. } \\
\text { Price for } 1 \text { bottle. } \\
200.00 \text { UAH in retail } \\
\end{array}$ & $\begin{array}{l}\text { Chardonnay } \\
\text { Sauvignon Blanc } \\
\text { Cabernet } \\
\text { Saperavi } \\
\text { Merlot } \\
\text { Sherry dry } \\
\text { Sherry dessert } \\
\text { Riesling }\end{array}$ & $\begin{array}{l}\text { National and } \\
\text { regional network } \\
\text { retail. Export } \\
\text { markets of Europe, } \\
\text { Japan }\end{array}$ \\
\hline \multicolumn{3}{|l|}{ Trademark was not } & $\begin{array}{l}\text { Grande Reserve: } \\
\text { «Great Wines« of } \\
\text { Ukraine, varietal and } \\
\text { blended AOC wines } \\
\text { Aging in a barrel } \\
18-24 \text { months. } \\
\text { Price for } 1 \text { bottle. } \\
500.00 \text { UAH in retail }\end{array}$ & $\begin{array}{l}\text { Chardonnay } \\
\text { Pink } \\
\text { Telti Kuruk } \\
\text { Cabernet } \\
\text { Muscat dessert vintage } \\
\text { Blending: Cabernet Merlot } \\
\text { Blending: Chardonnay- } \\
\text { Riesling }\end{array}$ & $\begin{array}{l}\text { Wine boutiques, } \\
\text { VIP HoReCa, } \\
\text { branded store } \\
\text { Shabo }\end{array}$ \\
\hline
\end{tabular}


Such decisions are made today very quickly, but must be very reasonable, which requires the presence of certain qualitative methodological approaches.

Based on the results of the analysis, it is advisable to determine the factors that influence the formation of the trademark policy of the enterprise:

- the role and level of the trademark;

- contribution to profit (marginality)

- level of popularity;

- dynamics of the target segment;

- conformity of trademark positioning to brand positioning

\section{SWOT analysis of research results}

Strengths. The strength of this research is the demonstration of the relevance and practical application of methodological approaches to the formation of a portfolio of brands by the example of the leading producer of alcoholic beverages.

Weaknesses. The weak side has certain problems in obtaining reliable information on other producers: the level of marginality is a commercial secret of producers.

Opportunities. Opportunities for further research are the expansion of the research base, the application of expert assessment methods and the construction on their basis of a mathematical model that will allow developing an algorithm for making decisions on the formation of a portfolio of trademarks.

Threats. Threats to the research results are influence of macro environment factors, change of legislative base, that is a high level of uncertainty, requires making corrections in the mathematical model.

\section{Conclusions}

1. It is determined that the concept of the brand is much broader than the trademark. A brand can be a name, a city name, a company name, a trademark, have a certain meaning and association and is recognized by consumers. At the same time, it is expedient to define such for trademark: it is a sign of the origin of the product, it identifies it with a certain source, registered in accordance with the law.

2. Trademarks should be classified according to the following criteria: trademark architecture; form; customer profiles; other indicators of brand success.

3. Based on the example of one of the leading producers of alcohol products LLC «ITC «Shabo» (Shabo village, Odessa region, Ukraine), the implementation of the process of portfolio management of trademarks is reviewed: the cancellation of certain product lines and the introduction of new ones due to changes in the positioning of the brand in whole. Failure to introduce into the production of the product, is popular due to the mismatch of positioning and the threat of the producer's reputation in general.

4. It is determined that in addition to the main economic factors, the formation of the portfolio of brands is also affected by:

- the role and level of the trademark;

- dynamics of the target segment;

- level of popularity;

- conformity of trademark positioning to brand positioning.
Further development of methodological approaches and creation of an algorithm will make it possible to take these decisions on the trademark policy of the wine industry enterprises with maximum efficiency.

\section{References}

1. Kim, W. C. Blue Ocean Strategy: How to Create Uncontested Market Space and Make the Competition Irrelevant [Text] / W. C Kim, R. Mauborgne. - Boston: Harvard Business School Press, 2004. -240 p.

2. Products Yellow Tail [Electronic resource] // Yellow Tail. - Available at: \www/URL: https://www.yellowtailwine.com/us/wines/

3. Brendy Global Spirit [Electronic resource] // Global Spirit. Available at: \www/URL: http://globalspirits.com.ua/uk

4. Shaw, R. Marketing Payback. Is your marketing profitable? [Text] / R. Shaw, D. Merrick. - New York: Prentice Hall, 2005. - 496 p.

5. Trofimov, Ya. I. Brending i identifikatsiya nastoyashhego i budushhego [Text] / Ya. I. Trofimov. - Odessa: Plaske, 2009. - $96 \mathrm{p}$

6. Hollis, N. Brand premium: how smart brands make more money [Text] / N. Hollis. - New York: Palgrave Macmillan, 2013. 225 p. doi:10.1007/978-1-137-51038-9

7. Stengel, J. Grow: How Ideals Power Growth and Profit at the World's Greatest Companies [Text] / J. Stengel. - New York: Crown Business, 2011. - 336 p.

8. Lindstrom, M. Brand Sense: Sensory Secrets Behind the Stuff We Buy [Text] / M. Lindstrom. - New York: Free Press, 2005. - 416 p.

9. Zook, C. The Great Repeatable Business Model [Text] / C. Zook, J. Allen // Harvard Business Review. - 2011. - Vol. 11, No. 1. P. 24-32.

10. Twyford, C. What Makes Big Brands Stay Big? [Text] C. Twyford. - Nielsen Featured Insights, 2010. - 54 p.

11. Kotler, P. In Destination Brands [Text] / P. Kotler, D. Gertner. Oxford: Butterworth-Heinemann, 2011. - 356 p.

12. Dlihach, A. O. Pryntsypy upravlinnia portfelem brendiv [Text] A. O. Dlihach // Visnyk Natsionalnoho Torhovelno-Ekonomichnoho Universytetu. - 2006. - No. 3. - P. 25-31.

13. Drennan, J. Examining the role of wine brand love on brand loyalty: A multi-country comparison [Text] / J. Drennan, C. Bianchi, S. Cacho-Elizondo, S. Louriero, N. Guibert, W. Proud // International Journal of Hospitality Management. - 2015. Vol. 49. - P. 47-55. doi:10.1016/j.ijhm.2015.04.012

14. Beverland, $M$. The «real thing»: Branding authenticity in the luxury wine trade [Text] / M. Beverland // Journal of Business Research. - 2006. - Vol. 59, No. 2. - P. 251-258. doi:10.1016/j.jbusres.2005.04.007

15. Carsana, L. Influence of iconic, indexical cues, and brand schematicity on perceived authenticity dimensions of private-label brands [Text] / L. Carsana, A. Jolibert // Journal of Retailing and Consumer Services. - 2018. - Vol. 40. - P. 213-220. doi:10.1016/j.jretconser.2017.10.006

16. Buk, L. M. Klasyfikatsiia tovarnykh marok yak osnova stratehi yikh rozvytku [Text] / L. M. Buk // Naukovyi visnyk NLTU Ukrainy - 2010. - No. 20.15. - P. 125-131. - Available at: \www/ URL: http://nltu.edu.ua/nv/Archive/2010/20_15/125_Buk.pdf

17. Shtovba, O. V. Klasyfikatsiia tovarnykh brendiv [Text] O. V. Shtovba // Visnyk Vinnytskoho politekhnichnoho instytutu. - 2005. - No. 4. - P. 25-33. - Available at: \www/ URL: http://oshtovba.vk.vntu.edu.ua/file/1904f00e3fdb154162 b8836c16c46312.pdf

18. Obsiahy vyrobnytstva promyslovoi produktsii v $2016 \mathrm{r}$. [Electronic resource] // Sait Derzhkomstat Ukrainy. - 2017. - Available at: \www/URL: http://www.ukrstat.gov.ua/operativ/ope-

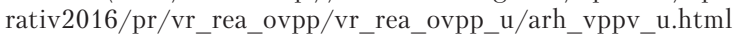

19. Kovalenko, I. A. Perspektivy proizvodstva ekologicheski chistoy vinogradarskoy produktsii na osnove sortov novogo selektsionnogo pokoleniya [Text] / I. A. Kovalenko, L. V. Gerus, M. G. Bankovskaya, M. G. Fedorenko // Napitki. Tekhnologii i innovatsii. - 2013. - No. 11-12. - P. 58-60.

20. Solodova, O. Global strategy of positioning of Ukraine wine production in Ukraine [Text] / O. Solodova, O. Golubyonkova // Ekonomika kharchovoi promyslovosti. - 2017. - Vol. 9 , No. 2. - P. $60-67$. 


\section{ИССЛЕДОВАНИЕ ФАКТОРОВ, ВЛИЯЮЩИХ НА МАРОЧНУЮ ПОЛИТИКУ ПРЕДЛРИЯТИЯ}

Проведено исследование классификации торговых марок, уточнено понятие бренда и торговой марки. Рассмотрен процесс формирования портфеля торговых марок на примере одного из ведущих производителей алкогольной продукции ООО «ПТК «Шабо» (с. Шабо, Одесская обл., Украина). Предложено перечень факторов, которые необходимо учитывать при принятии решения о формировании портфеля торговых марок.
Ключевые слова: торговая марка, марочная политика, портфель торговых марок, производители алкогольной продукции.

Solodova Olga, Postgraduate Student, Department of Marketing, Entrepreneurship and Trade, Odessa National Academy of Food Technologies, Ukraine, e-mail: o.solodova@shabo.ua, ORCID: https:// orcid.org/0000-0003-4106-8733

Golubyonkova Olena, PhD, Associate Professor, Department of Marketing, Entrepreneurship and Trade, Odessa National Academy of Food Technologies, Ukraine, e-mail: Lena.golubenkova@gmail.com, ORCID: https://orcid.org/0000-0001-9846-2948
Shevtsiv L.

INVESTIGATION OF THE MECHANISM
OF INTERREIATION BETWEEN
ACCOUNTING AND BUDGETING IN THE
ENTERPRISE MANAGEMENT SYSTEM:
THE STRATEGIC ASPECT

Проаналізовано результати останніх досліджень науковців $і$ визначено принципи, значення бюджетування, його взаємозв'язок з обліком в системі управління діяльністю підприємств. Ідентифіковано вплив різних видів обліку і можливості інтеграцї із складовими системи управління для досягнення стратегічних иілей. Визначено послідовність формування звітності за центрами відповідальності та інформаційний зв'язок між бюджетами, иільовою собівартістю та нормативами витрат. Сформульовано переваги механізму взаємозв'язку бюджетування з бухгалтерським обліком.

Ключові слова: система стратегічного управління, обліково-аналітичне забезпечення, взаємозв'язок бюджетування з бухгалтерським обліком.

\section{Introduction}

Eurointegration processes, toughening of business conditions cause strengthening of own competitive positions in the market. This affects the construction of an effective «system of strategic management, due to the understanding of the enterprise as an open system that actively interacts with the external environment, receiving in it inputs and the expected result of activity at the exit» [1].

It is in this plane that proper performance of the service function by accounting will be an effective tool to meet the needs of the accounting company's management. And it will also promote the introduction of budgeting to achieve the strategic goals set, to implement budgets, to identify deviations and eliminate the causes of their occurrence. After all, a clear organization of the budgeting process - a tool for implementing the planning function and the method of financial management, will help to increase the efficiency of doing business by Ukrainian enterprises from 25-50\% and reduce the costs of the enterprise by $10-15 \%$ due to improved management quality [1]. According to experts, enterprises that do not make budgets lose up to $20 \%$ of their revenues per year [2]. The above tendencies actualize the use of additional ac- counting and budgeting capabilities, which will allow to form a qualitatively new strategic level of management, adapted to the requirements of the present.

\section{The object of research and its technological audit}

The object of research is the system of accounting and budgeting in interrelation and continuous development.

To increase the effectiveness of the management cycle, enterprises need to reorganize their internal structure and structural divisions, using management methods, one of which is budgeting. In particular, the lack of stable interrelationships in budgeting and strategic goals indicates inefficient implementation of strategic management as the basis for long-term stable business development. Specified on the basis of information of economic activities of the Ukrainian engineering enterprise under study it is possible: to generalize approaches to the organization of the budgeting process; to systematize factors and directions of development of its accounting system, subsystems of management accounting and reporting; as an improvement use a foreign scheme [3]. So, Fig. 1 shows the scheme of the stages of the budget process of production units and the obtained results. 